\title{
Establishment of seed in vitro conditions of Swietenia macrophylla to obtain aseptic seedlings
}

\section{Establecimiento de semilla en condiciones de in vitro de Swietenia macrophylla para obtención de plántulas asépticas}

\author{
CRUZ-GUTIÉRREZ, Esmeralda J. ${ }^{1}{ }^{* *}$, GÓMEZ-REYES, Luis A ${ }^{1}$. and CORTES-AGUILAR, Jesús ${ }^{2}$ \\ ${ }^{I}$ Centro Nacional de Recursos Genéticos del Instituto Nacional de Investigaciones Forestales, Agrícolas y Pecuarias. \\ ${ }^{2}$ Secretaría de Medio Ambiente y Desarrollo Territorial
}

ID $1^{\text {st }}$ Autor: Esmeralda J., Cruz-Gutiérrez / ORC ID: 0000-0002-2092-5284, CVU CONACYT ID: 44784

ID $1^{\text {st }}$ Coautor: Gómez-Reyes, Luis A. / ORC ID: 0000-0002-3551-6555

ID $2^{\text {nd }}$ Coauthor: Jesús, Cortes-Aguilar

DOI: $10.35429 / J N A S .2019 .19 .6 .28 .31$

Received June 21, 2019; Accepted December 30, 2019

\begin{abstract}
The mahogany, Swietenia macrophylla, due to its economic importance, occupies an important place within the regional flora of southern and southeastern Mexico. The objective of this work is to obtain a mahogany seed disinfection protocol for its establishment in vitro. The seeds were left in imbibition for 24 hours, then the seed was washed with running water and soap for 3 minutes. Subsequently, within the laminar flow hood, different treatments were carried out, the control $30 \mathrm{~min}$ in captan, treatment 1: $30 \mathrm{~min}$ in capture $1.5 \mathrm{~min}$ in $70 \%$ ethanol and $3 \mathrm{~min}$ in $30 \%$ chlorine. Treatment 2: $30 \mathrm{~min}$ in captan 1.5 in $70 \%$ ethanol and $4 \mathrm{~min}$ in 30\% chlorine. Treatment 3: $30 \mathrm{~min}$ in captan, $1.5 \mathrm{~min}$ in $70 \%$ ethanol and $9 \mathrm{~min}$ in $30 \%$ sodium hypochlorite. The data were subjected to analysis of variance and comparison test of Tukey means (Tukey, $\alpha=0.05$ ). The variables that were evaluated were germination and contamination in the environment. It was observed that there were no significant differences in seed germination. Regarding contamination, treatment three presented the least contamination.
\end{abstract}

Aseptic, Forestry, In Vitro

\begin{abstract}
Resumen
La caoba, Swietenia macrophylla, por su importancia económica, ocupa un lugar importante dentro de la flora regional del sur y sureste de México. El objetivo de este trabajo es obtener un protocolo de desinfección de semilla de caoba para su establecimiento in vitro. Las semillas se dejaron en imbibición por 24 horas, después se lavó la semilla con agua corriente y jabón durante 3 minutos. Posteriormente, dentro de campana de flujo laminar, se realizaron diferentes tratamientos, el testigo 30 min en captán, tratamiento 1: $30 \mathrm{~min}$ en captan 1.5 min en etanol al $70 \%$ y 3 min en cloro al $30 \%$. Tratamiento 2: 30 min en captán 1.5 en etanol al 70\% y 4 min en hipoclorito de sodio al 30\%. Tratamiento 3: 30 min en captán, 1.5 min en etanol al $70 \%$ y 9 min en cloro al 30\%. Los datos se sometieron a análisis de varianza y prueba de comparación de medias Tukey (Tukey, $\alpha=0.05$ ). Las variables que se evaluaron fue la germinación y la contaminación en el medio. Se observó que no presentaron diferencias significativas en la germinación de la semilla. En cuanto a la contaminación el tratamiento tres fue el que presentó menor contaminación.
\end{abstract}

Asepsia, Forestal, In Vitro

Citation: CRUZ-GUTIÉRREZ, Esmeralda J., GÓMEZ-REYES, Luis A. and CORTES-AGUILAR, Jesús. Establishment of seed in vitro conditions of Swietenia macrophylla to obtain aseptic seedlings. Journal of Natural and Agricultural Sciences. 2019, 6-19: 28-31

\footnotetext{
*Correspondence to Author (cruz.esmeralda@inifap.gob.mx)

$\dagger$ Researcher contributing first author
} 


\section{Introduction}

Mahogany (Swietenia macrophylla), is native to the warm-humid regions of tropical America. It occupies an important place within the flora of southern and southwest Mexico. In the state of Campeche, mahogany is a natural component in the entity's tropical forests (Vázquez Soto 1981; SARH 1985). It is considered one of the most valuable timber species in the world (Lamb, 1996). It is a timber forest species of multiple uses, appreciated for its hardness, strength, beauty and quality (Carranza et al., 2013). Their populations have decreased rapidly in recent years in various locations as a result of the change in land use and the over-exploitation to which they have been subjected. It has the potential to be used in crops and forage alleys of multiple strata and improved fallows.

It is common to find it in the Mayan family gardens (Yucatan) and is used to shade coffee plantations. Sometimes it is planted in association with Tectona grandis or Tabebuia pentaphylla or with the "taungya" system (CONABIO, 2019). The selective use of mahogany has diminished its natural regeneration capacity in many areas and in some places the species has disappeared, with trees with a diameter of commercial value becoming increasingly scarce. On the other hand, the application of tissue culture techniques in woody plants offers a valuable alternative for the propagation of elite trees (Collado et al., 2004), in vitro conditions.

This technique can be used, both for the mass propagation of the species, and for the conservation of elite trees. On the other hand, the National Center for Genetic Resources of the National Institute of Forestry, Agricultural and Livestock Research (CNRG-INIFAP), aims to protect agricultural-forest, livestock, aquatic and microbial genetic resources, for medium-term conservation long term. In the AgriculturalForestry Laboratory section orthodox seeds, accessions of different forest species arrive, both orthodox seeds and recalcitrant seeds, performing the necessary work for the conservation of these species. On the other hand, seeds are also established under in vitro conditions to obtain mature embryos, it is a promising technique to induce rapid germination and pathogen-free seedlings, in addition to having low costs (Medel-Narváez et al., 2001)
For this reason, the objective of this work was to develop the protocol for the establishment in vitro of Swietenia macrophylla seeds received in the CNRG-INIFAP for long-term conservation. Once the seeds are established under in vitro conditions, and germinated, the multiplication protocol will be developed to carry out the conservation protocols in the medium and long term.

\section{Materials and methods}

Seeds that were in good physical condition were selected. Subsequently, the disinfection protocol was performed. A washing with $1 \%$ powder detergent was performed for a period of 10 minutes, this step was performed twice more. Subsequently, the seeds were left in imbibition for $16 \mathrm{~h}$ in double distilled water, then a new washing with $1 \%$ powder detergent was carried out for a period of 10 minutes. $3 \mathrm{~g} \cdot \mathrm{L}^{-1}$ was left in a captan solution for 30 minutes, then in a $70 \% \mathrm{v} / \mathrm{v}$ ethanol solution for a period of 1.5 minutes followed by introducing them into a $30 \%$ sodium hypochlorite solution $\mathrm{v} / \mathrm{v}$ for different times (Table 1). Three washings were given inside the laminar flow hood with sterile double-distilled water. The medium used for the establishment was $100 \%$ MS with $20 \mathrm{~g} \cdot \mathrm{L}^{-1}$ sucrose, $1 \mathrm{~g} \cdot \mathrm{L}^{-1}$ activated carbon, $1 \mathrm{~mL} \cdot \mathrm{L}^{-1}$ antibiotic (PPMTM: Plant Preservative Mixture), $1 \mathrm{~g} \cdot \mathrm{L}^{-1}$ antioxidant, $8 \mathrm{~g} \cdot \mathrm{L}^{-1}$ agar. The data were subjected to analysis of variance and comparison test of Tukey means (Tukey, $\alpha=$ $0.05)$. The variables that were evaluated were germination and contamination in the environment.

\begin{tabular}{|l|r|r|r|}
\hline Treatments & $\begin{array}{c}\text { Captán 3 } \\
\text { gL }^{-1}\end{array}$ & $\begin{array}{c}\mathbf{7 0 \%} \\
\text { ethanol }\end{array}$ & $\begin{array}{c}\text { Sodium } \\
\text { Hypochlorite } \\
\mathbf{3 0 \%}\end{array}$ \\
\hline & \multicolumn{4}{|c|}{ Minutes } \\
\hline Witness & 30 & 0 & 0 \\
\hline $\mathbf{2}$ & 30 & 1.5 & 4 \\
\hline $\mathbf{3}$ & 30 & 1.5 & 9 \\
\hline
\end{tabular}

Table 1 Treatments performed in the experiment 

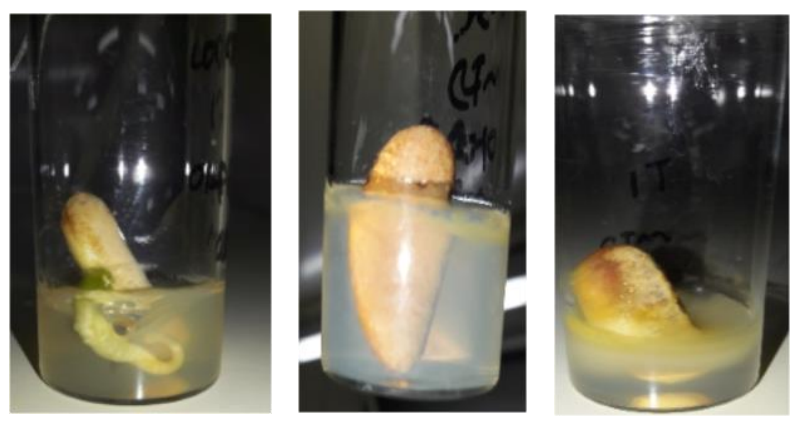

Figure 1 Establishment of mahogany seed under in vitro conditions
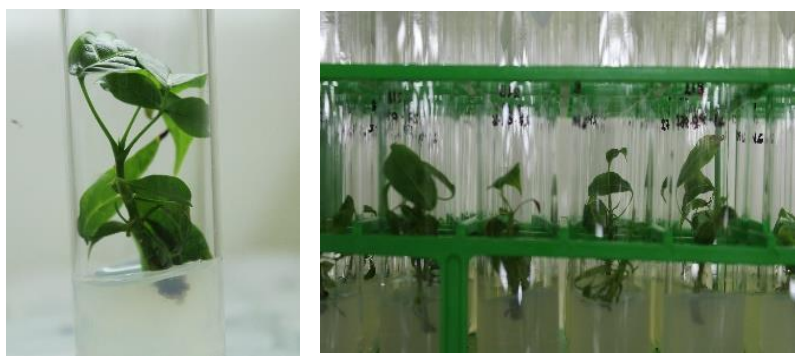

Figure 2 Mahogany seedlings obtained from seed under in vitro conditions

\section{Results}

According to the results obtained, it was observed that, in the germination variable, there was no significant difference between the treatments with respect to control. On the other hand, in the contamination variable it was observed that treatment 3 where 9 minutes of sodium hypochlorite was left, presented a significant difference with respect to the other treatments.

\begin{tabular}{|l|r|r|}
\hline Treatment & \multicolumn{2}{c|}{ Variables } \\
\hline & Germination & Pollution \\
\hline Witness & $0.8000 \mathrm{a}$ & $1.000 \mathrm{a}$ \\
\hline T1 & $0.3000 \mathrm{a}$ & $0.5000 \mathrm{ab}$ \\
\hline T2 & $0.4000 \mathrm{a}$ & $0.5000 \mathrm{ab}$ \\
\hline T3 & $0.3000 \mathrm{a}$ & $0.2000 \mathrm{~b}$ \\
\hline
\end{tabular}

Table 2 Results obtained from the statistical analysis

\section{Conclusions}

It was observed that a longer time in sodium hypochlorite decreased the presence of microorganisms in the medium of establishment of mahogany seeds. In general, vegetative explants are established under in vitro conditions, such as apexes of mahogany seedlings (Collado et al., 2004), to obtain a uniform offspring, with genetically identical plants, called clones (Borges et al., 2009).
The most used explant for in vitro propagation processes are the vegetative buds of plants (Castillo, 2008) and for long-term conservation apical apices (Yamamoto et al., 2019).

Among the $\mathrm{s}$ used in the disinfection of plant material are sodium hypochlorite $(\mathrm{NaClO})$, calcium hypochlorite $(\mathrm{CaClO})$, ethanol $\left(\mathrm{C}_{2} \mathrm{H}_{5} \mathrm{OH}\right)$ and mercury bichloride $\left(\mathrm{HgCl}_{2}\right)$, where calcium hypochlorite has been the compound most frequently used in different investigations related to the establishment protocols under in vitro conditions of plant material, at different concentrations and times (Borges et al., 2009). In addition, this product is easily acquired and economical.

There are several investigations where chlorine hypochlorite is used at low concentrations, as in the case of mahogany apices and nodal segments with concentrations of $2.0 \%$ and $3.0 \%$ combined with three exposure times, 10 and 30 min (Collado et al. , 2004). As observed, they are low concentrations because the explant has soft tissue. As in the establishment of Discorea alata L., the percentage of chlorine used is 1.5 to $2.5 \%$, at times of 10, 20 and 30 min immersion (Borges et al., 2009). In both cases the longest immersion time was the one that decreased the contamination by microorganisms.

In this work, only a concentration of sodium hypochlorite was evaluated, at 30\% similar to the work reported by Medel-Narváez et al. (2001) where the seed of Ariocarpus fissuratus var. Fissuratus (Eng.) Shumann with $20 \%$ sodium hypochlorite, although it was observed that it has a better result when the seeds are exposed to $100 \%$ sodium hypochlorite. Although in this work $30 \%$ sodium hypochlorite was optimal for seed disinfestation.

On the other hand, what coincides with other works carried out to disinfect the explant, is that, with a longer exposure time to sodium hypochlorite, the possibility that the environment where the explant is established is not contaminated is greater.

However, care must be taken that the explant does not necrose when exposed to sodium hypochlorite, since prolonged exposure to this solution can be necrotic, whether it is soft tissue or not germinating if it is seed. 
As observed in the work of MedelNarváez et al. (2001), where the results of the analysis of variance show that the higher the concentration of sodium hypochlorite, the lower the rate of contamination by fungi and bacteria, but not because of the incidence of oxidation.

\section{Acknowledgment}

To the National Forestry Commission (CONAFOR) for financing this research through project No. 11385232709.

\section{Conclusions}

The use of sodium hypochlorite is a good element for the disinfestation of explants, however, care must be taken since depending on the type of explant or species is the concentration that should be used and the time of immersion in the solution, taking care that the explant to be disinfested does not necrose or rust.

\section{References}

Borges García, M., Estrada Abeal, E., Pérez Rodríguez, I. y Meneses Rodríguez, S. (2009). Uso de distintos tratamientos de desinfección en el cultivo in vitro de Dioscorea alata L. clon caraqueño. Revista Colombiana de Biotecnología. 2: 127-135.

Carranza Patiño, M., Reyes Morán, H., Mora Silva, W., Cevallos Falquez, O., Escobar Troya, A., Cadme Arévalo, M., Nieto Rodríguez, J. y Morante Carriel J. (2013). Propagación clonal in vitro de Swietenia macrophylla King (Caoba). Ciencia y Tecnología 6(2): 1-8.

Castillo, A. (2008). Propagación de plantas por cultivo in vitro: una biotecnología que nos acompaña hace mucho tiempo. Las Brujas, Uruguay: AR-VITRO, INIA, 8p.

Collado, R., Barbón, R., Agramonte, D., Jiménez, F., Pérez, M., Gutiérrez, O., y Ramírez D. (2004). Establecimiento in vitro de ápices y segmento nodales de Swietenia macrophylla King. Biotecnología vegetal. 4 (3): 143-146.

Comisión Nacional para el Conocimiento y Uso de la Biodiversidad (CONABIO). (2018). Swietenia macrophylla. Disponible en línea en: http://www.conabio.gob.mx/conocimiento/info _especies/arboles/doctos/37-melia5m.pdf. (accesado el 15 de septiembre de 2019).
Lamb, F. B. (1996). Mahogany of tropical America: Its ecology and management, Ann. Arbor: University of Michigan Press, p. 219.

Medel-Narváez, A., Flores-Hernández, A., Armendáriz-Erivez, S. y Santamaría-César, E. (2001). Técnicas de desinfestación y siembra in vitro de embriones maduros de falso peyote (Ariocarpus fissuratus var. fissuratus (Eng.) Shumann), (Cactaceae). Revista Chapingo Serie Zonas Aridas 2(1):53-59.

Yamamoto, S., Fukui, K. y Niino T. (2019). A new cryopreservation method for vegetatively propagated plant genetic resources using aluminum cryo-plates. Disponible en línea en: https://pdfs.semanticscholar.org/67e8/750faeab a7e321a9ab9693b7c7078caddc32.pdf. (accesado el 15 de septiembre de 2019). 